\title{
STUDI INSTALASI PENGOLAHAN AIR LIMBAH DI RSUD dr. R. GOETENG TAROENADIBRATA PURBALINGGA TAHUN 2015
}

\author{
Tia Agustin ${ }^{1)}$, Hari Rudijanto ${ }^{2)}$ \\ Jurusan Kesehatan Lingkungan, Politeknik Kesehatan Kemenkes Semarang, \\ Jl. Raya Baturaden KM 12 Purwokerto, Indonesia
}

\begin{abstract}
Abstrak
Rumah Sakit Umum Daerah dr. R. Goeteng Taroenadibrata Purbalingga merupakan rumah sakit type C yang terletak di Jl. Tentara Pelajar No. 22 berpotensi menghasilkan limbah cair yang berbahaya. Tujuan penelitian ini mengetahui besarnya efisiensi kinerja IPAL dalam mereduksi kandungan BOD, COD, TSS, Suhu, pH dan Bakteriologis limbah cair rumah sakit dr. R. Goeteng Taroenadibrata Purbalingga. Penelitian ini adalah Deskriptif. Pengumpulan data dilakukan dengan cara Observasi dan wawancara. Pengolahan data secara Deskriptif dilakukan dengan analisis tabel dan prosentase untuk menggambarkan kondisi kualitas limbah cair. Hasil pemeriksaan laboratorium menunjukan bahwa pengolahan limbah cair rumah sakit $d r$. $R$. Goeteng Taroenadibrata Purbalingga kandungan BOD $_{5}$ di Efluent yaitu 25,03 mg/l, COD 102,00 mg/l, TSS $702 \mathrm{mg} / \mathrm{l}, \mathrm{pH}$ 8,27, Suhu $27^{\circ} \mathrm{C}$ dan Mikrobiologi (Kuman Gol. Koli) 2400 MPN/100 ml. Seluruh sampel yang di uji ada yang belum memenuhi standar baku mutu air limbah yang sudah ditetapkan, untuk batas pencemaran parameter air limbah yang diolah karena hasil COD dan TSS yang diperiksa diatas standar baku mutu.
\end{abstract}

Kata kunci : kinerja IPAL; kualitas limbah cair; rumah sakit

\begin{abstract}
[Studies of wastewater treatment plants in dr. R. Goeteng Taroenadibrata Purbalingga 2015] Regional General Hospital dr. R. Goeteng Taroenadibrata Purbalingga a hospital type C is located at Jl. Students' Army No. 22 potentially hazardous liquid waste. This research purposes to know the magnitude of the efficiency performance of the WWTP in reducing the content of BOD, COD, TSS, temperature, $p H$ and wastewater Bacteriological hospital $d r$. R. Goeteng Taroenadibrata Purbalingga. This is a descriptive study. Data collection is done by observation and interviews. Descriptive data processing performed by the analysis of tables and percentages to describe the quality of the effluent. Results of laboratory tests showed that the wastewater treatment hospital dr. R. Goeteng Taroenadibrata Purbalingga content of BOD5 in the effluent that is $25.03 \mathrm{mg} / \mathrm{l}$, COD $102.00 \mathrm{mg} / \mathrm{l}$, TSS $702 \mathrm{mg}$ / l, pH 8.27, temperature $27^{\circ} \mathrm{C}$ and Microbiology (Germs Gol. Koli) $2400 \mathrm{MPN} / 100 \mathrm{ml}$. The entire sample in the test there is not yet meet the quality standards of waste water that has been set, to limit pollution of the treated waste water parameters as COD and TSS results are checked on quality standards.
\end{abstract}

Keywords : performance IPAL; effluent quality; hospital

\section{PENDAhuluan}

Upaya kesehatan lingkungan ditunjukan untuk mewujudkan kualitas lingkungan yang sehat, baik secara fisik, kimia, biologi maupun sosial yang memungkinkan setiap orang mencapai derajat kesehatan yang setinggi-tingginya (UU RI No. 36 Tahun 2009, Pasal 126) .

Rumah sakit adalah sarana upaya kesehatan yang menyelenggarakan kegiatan pelayanan kesehatan serta dapat berfungsi sebagai tempat pendidikan tenaga kesehatan dan penelitian. (KEP58/MENLH/12/1995, pasal 1). Dalam pengolahan limbah, rumah sakit tidak hanya menghasilkan limbah organik dan anorganik, tetapi juga limbah infeksius yang mengandung bahan beracun dan berbahaya (B3). Dari keseluruhan limbah rumah sakit, sekitar 10 - $15 \%$ di antaranya merupakan

1) Email : agustiint@rocketmail.com

2) Email : hariokey2000@yahoo.com limbah infeksius yang mengandung logam berat, antara lain mercuri (Hg). Sekitar 40 \% lainnya adalah limbah organik yang berasal dari sisa makan, baik dari pasien dan keluarga pasien maupun instalasi gizi. Sisanya merupakan limbah anorganik dalam bentuk botol bekas infus dan plastik.

Air limbah yang berasal dari rumah sakit merupakan salah satu sumber pencemaran air yang sangat potensial. Hal ini disebabkan karena air limbah rumah sakit mengandung senyawa organik yang cukup tinggi, mengandung senyawa-senyawa kimia yang berbahaya serta mengandung mikroorganisme pathogen yang dapat menyebabkan penyakit. Pengelolaan limbah RS yang tidak baik akan memicu resiko terjadinya kecelakaan kerja dan penularan penyakit. Tentu saja RS sebagai institusi yang sosioekonomis karena tugasnya memberikan 
pelayanan kesehatan kepada masyarakat, tidak terlepas dari tanggung jawab pengelolaan limbah yang dihasilkan. Untuk menjamin keselamatan dan kesehatan awak RS maupun orang lain yang berada di lingkungan RS dan sekitarnya. Limbah rumah sakit adalah semua limbah yang dihasilkan dari kegiatan rumah sakit dalam bentuk padat, cair ,dan gas .

Limbah cair adalah gabungan atau campuran dari air dengan bahan - bahan pencemar yang terbawa oleh air baik dalam keadaan terlarut ataupun tersuspensi yang terbuang dari sumber domestik (perkantoran, perumahan, dan perdagangan ) sumber industry dan pada saat tertentu tercampur dengan air tanah, air permukaan atau air hujan (Soeparman dan Suparmin 2001, h 12) .

Limbah cair rumah sakit yang dibuang ke lingkungan tidak diolah dengan benar akan menimbulkan kualitas lingkungan, yaitu banyak sekali resiko atau dampak yang ditimbulkan terhadap gangguan kesehatan manusia, penurunan kualitas lingkungan, dan gangguan terhadap kerusakan benda yang disebabkan oleh garam - garam yang terlarut, air yang berlumpur dan sebagiannya dapat menurunkan kualitas bangunan disekitar rumah sakit. Perlunya Pengolahan limbah cair di rumah sakit yaitu untuk mengolah limbah cair yang dihasilkan agar tidak berdampak buruk pada badan air atau kualitas air tanah sekitarnya.

Rumah sakit dr. R. Goeteng Taroenadibrata Purbalingga sebagai salah satu sarana kesehatan milik pemerintah daerah kota Purbalingga memiliki peran penting dalam pelayanan kesehatan masyarakat kota Purbalingga. Rumah Sakit umum dr.Goeteng Taroenadibrata saat ini merupakan rumah sakit kelas C. Survey awal yang di lakukan di Rumah Sakit Umum Daerah dr. R. Goeteng Taroenadibrata Purbalingga sudah memiliki sarana instalasi pengolahan air limbah atau IPAL, akan tetapi keadaannya rusak sehingga tidak berfungsi dengan baik. Tidak semua air limbah atau air buangan ke IPAL , karena terdapat ruang yang menggunakan septik tank tersendiri atau khusus.

Sumber air limbah berasal dari kamar mandi, WC, wastafel, rawat inap, instalasi Gizi, loundry, ruang bersalin, ruang operasi, instalasi pemulasaran jenazah, taman RSUD, dll. Karakteristik limbah cair selalu di periksa secara rutin tiap 3 bulan sekali oleh Laboratorium Kesehatan Masyarakat milik Dinas Kesehatan Kabupaten Purbalingga yang bekerja sama dengan RSUD, adapun karateristik limbah yang diperiksa antara lain pemeriksaan effluent air limbah yang meliputi pemeriksaan secara kimia dan fisika. Untuk pemeriksaan Fisika meliputi SUHU dan TSS, sedangkan pemeriksaan secara Kimia meliputi $\mathrm{pH}$, BOD, COD, Amoniak, dan Phospat. Berdasarkan dari hasil data yang diperoleh, hasil parameter yang belum memenuhi syarat atau standar Baku Mutu Air Limbah menurut Peraturan Daerah Jawa Tengah No. 05 Tahun 2012 yaitu pada pemeriksaan bulan Agustus 2014 parameter BOD, COD dan TSS masih belum memenuhi syarat Baku Mutu Air Limbah. Rumah sakit dr. R. Goeteng Taroenadibrata Purbalingga terletak sangat dekat dengan pemukiman penduduk. Badan air sebagai tempat pembuangan air limbah pun melewati pemukiman penduduk yang dialirkan melalui sungai atau pesawahan.

Penelitian ini dilakukan dengan tujuan untuk mengetahui Kinerja IPAL di RSUD dr. R. Goeteng Taroenadibrata Purbalingga

\section{BAHAN DAN METODE}

Jenis penelitian ini adalah penelitian Deskriptif yaitu mengamati proses pengelolahan air limbah di rumah sakit dan mengumpulkan data laboratorium. Sampel dalam penelitian ini adalah air limbah sebelum melalui pengolahan dan sesudah melalui pengolahan. Diambil sampelnya kemudian diperiksa kualitas parameter limbah cair, antaranya $\mathrm{BOD}_{5}$, COD, TSS, pH, Suhu, dan Kuman Gol. Koli. Alat yang digunakan adalah gelas ukur, pipet ukur, pipet tetes, backer glass, gelas winkler/botol oksigen winkler, $\mathrm{pH}$ stick indicator, gelas kimia, thermometer air, tabung durham. Bahan yang digunakan adalah air limbah. Analisis data yang digunakan adalah analisis data dari hasil laboratorium kemudian dibandingkan dengan stardar atau syarat - syarat undang - undang yang berlaku .

\section{III.HASIL DAN PEMBAHASAN}

Kualiatas Fisik air limbah untuk Suhu di inlet pada bulan April 2015 adalah $27,2^{\circ} \mathrm{C}$ dengan outlet $27^{\circ} \mathrm{C}$. Kadar maksimum Suhu dalam limbah cair menurut Perda Prop. Jateng No.05 tahun 2012 adalah $30^{\circ} \mathrm{C}$. Effluen air limbah untuk parameter Suhu adalah $27^{\circ} \mathrm{C}$. Hal ini berarti kualitas parameter suhu yang dihasilkan baik dan sudah memenuhi standar baku mutu yang ditetapkan. TSS inlet pada bulan April 2015 adalah 716 mg/l dengan TSS outlet adalah $702 \mathrm{mg} / \mathrm{l}$. Sehingga di dapatkan efisiensi untuk TSS bulan April 2015 efisiensi TSS 1,95\%. Kadar maksimum TSS dalam limbah cair menurut Perda Prop. Jateng No. 05 tahun 2012 adalah 30 mg/l. Effluen air limbah untuk parameter TSS adalah 702 mg/l, hasil ini sangat jauh diatas baku mutu yang sudah ditetapkan yaitu $30 \mathrm{mg} / \mathrm{l}$. Hal ini berarti kualitas effluent TSS yang dihasilkan sangat buruk. Dapat disimpulkan bahwa pengolahan limbah cair di IPAL sangat buruk terutama untuk menurunkan kadar TSS pada limbah yang diolah.

Kualitas Kimia air limbah, pH inlet pada bulan April 2015 adalah 7,3 dengan pH outlet adalah 8,27. $\mathrm{pH}$ effluen limbah cair yang dibuang ke sungai $\mathrm{pH}$ nya adalah 8,27. pH effluen ini masih masuk kisaran baku mutu air limbah yang telah ditetapkan yaitu 6,09,0. BOD $_{5}$ inlet pada bulan April 2015 adalah 40,63 $\mathrm{mg} / \mathrm{l}$ dengan outlet 25,03 mg/l. Sehingga didapatkan efisiensi untuk $\mathrm{BOD}_{5}$ 38,3\%.Kadar maksimum $\mathrm{BOD}_{5}$ dalam air limbah menurut Perda Prop. Jateng No. 05 tahun 2012 adalah 30 mg/l. Effluen air limbah untuk parameter $\mathrm{BOD}_{5}$ adalah 25,03 mg/l, hasil ini sudah 
sesuai baku mutu yang telah ditetapkan yaitu $30 \mathrm{mg} / \mathrm{l}$. Hal ini berarti kualitas effluent $\mathrm{BOD}_{5}$ yang dihasilkan sudah baik. Dapat disimpulkan bahwa pengolahan limbah cair di IPAL baik terutama untuk menurunkan kadar $\mathrm{BOD}_{5}$ pada limbah yang diolah.COD inlet pada bulan April 2015 adalah $134,00 \mathrm{mg} / \mathrm{l}$ dengan COD outlet $102,00 \mathrm{mg} / \mathrm{l}$. Sehingga di dapatkan efisien untuk COD 23,8\%.

Kadar maksimum COD dalam limbah cair menurut Perda Prop. Jateng No. 05 tahun 2012 adalah $80 \mathrm{mg} / \mathrm{l}$. Effluen air limbah parameter COD 102,00 $\mathrm{mg} / \mathrm{l}$, hasil ini diatas baku mutu air limbah yang telah ditetapkan yaitu $80 \mathrm{mg} / \mathrm{l}$. Hal ini berarti kualitas effluen COD yang dihasilkan buruk. Dapat disimpulkan bahwa pengolahan limbah cair di IPAL belum memenuhi standar baku mutu air limbah.

Kualitas Mikrobiologi air limbah, Kuman Golongan Coli inlet pada bulan April 2015 adalah 3500 MPN/100 ml dengan Outlet adalah 2400 MPN/100 ml. Kadar maksimum kuman golongan coli dalam limbah cair menurut Perda Prop. Jateng No. 05 tahun 2012 adalah 5000 MPN/100 ml.Effluen air limbah Gol. Coli 2400 MPN/100ml.Dapat disimpul kan bahwa kualitas mikrobiologi effluen yang dihasil kan sangat baik karena sudah memenuhi standar baku mutu air limbah yang telah ditetapkan yaitu 5000 MPN/100 ml.

F/M Rasio (Food \& Mikroorganisme Ratio),yaitu: perbandingan antara substrat (F : food) terhadap mikroorganisme (M). Dalam proses lumpur aktif convensional,dapat berjalan dengan baik apabila F/M ratio berkisar $0,2 \quad-\quad 0,6 \mathrm{~kg} \quad \mathrm{BOD} / \mathrm{kg}$ MLSS. Kebutuhan oksigen yaitu 57,69 kg/hari. Dan untuk waktu detensi dapat disimpulkan bahwa sudah memenuhi yaitu 5,69 jam. Batas Minimum dan Maksimum nya untuk waktu detensi yaitu 4-8 jam.

\section{IV.KESIMPULAN}

Proses pengolahan Air Limbah di RSUD dr. Goeteng Taroenadibrata limbah cairnya dilakukan dengan menggunakan 7 tahap yaitu : Aliran masuk (Bak penampung), Penyaringan, Equalisasi, Lumpur Aktif, Aerasi, Sedimentasi, Bak Control.

\section{DAFTAR PUSTAKA}

Budiman Chandra, 2007, Pengantar Kesehatan Lingkungan, Jakarta : Penerbit Buku Kedokteran EGC.
Depkes RI, 2009, Undang - Undang Republik Indonesia Nomer 36 Tahun 2009 pasal 126, Jakarta : Depkes RI

KEPMENLH, 1995, Keputusan Menteri Lingkungan Hidup No. 58/MENLH/12/1995 Tentang Rumah Sakit. Jakarta

Hefni Effendi, 2003, Telaah Kualitas Air bagi Pengolahan Sumber Daya dan Lingkungan Perairan, Yogyakarta : Kanisius.

Sri Rezeki Indah Astian, 2014, Studi Pengolahan Limbah Cair Penyamakan Kulit di PT Budi Makmur Kecamatan Gedong Kuning Yogyakarta Tahun 2014, Karya Tulis Ilmiah, Purwokerto : Politeknik Kesehatan Kementerian Kesehatan Semarang

Perda Provinsi Jateng, 2012 , Peraturan Daerah Provinsi Jawa Tengah No. 5 Tahun 2012 Tentang Baku Mutu Air Limbah Rumah Sakit. Semarang

Soeparman, Suparmin, 2002, Pembuangan Tinja dan Air Limbah : Suatu Pengantar, Jakarta : Penerbit Buku Kedokteran EGC.

Undang - Undang RI, 2009, Peraturan Menteri Kesehatan Republik Indonesia Nomer 44 Tahun 2009 Tentang Rumah Sakit.

Sujarwo, 2008, Studi Kinerja Pengolahan Air Limbah Bersama Industri Tekstil CV. Ezritex di Kota Pekalongan Tahun 2008, Karya Tulis Ilmiah, Purwokerto : Poltekkes Kesehatan Kementerian Kemenkes Semarang.

Depkes RI, 1987, Peraturan Menteri Kesehatan Republik Indonesia Nomer 173/MENKES/1987 Tentang Pencemaran Air. Jakarta

PERMENKES RI, 2010, Peraturan Menteri Kesehatan Republik Indonesia No. 340/MENKES/PER/III/2010 Tentang Klasifikasi Rumah Sakit. Jakarta

Sugeng Abdullah, 2002, Problem dan Solusi Instalasi Pengolahan Air Limbah, Purwokerto : Yasamas 